\title{
Human and environmental associates of local species-specific abundance in a multi-species deer assemblage
}

\author{
Valentina Zini $^{1,2}$ (]) $\cdot$ Kristin Wäber $^{1,3} \cdot$ Karen Hornigold $^{4} \cdot$ Ian Lake ${ }^{1} \cdot$ Paul M. Dolman $^{1}$
}

Received: 6 April 2021 / Revised: 14 September 2021 / Accepted: 1 October 2021 / Published online: 22 October 2021

(c) The Author(s) 2021

\begin{abstract}
Understanding how habitat, landscape context, and human disturbance influence local species-specific deer density provides evidence informing strategic management of increasing deer populations. Across an extensive $\left(187 \mathrm{~km}^{2}\right)$ heterogeneous forest-mosaic landscape in eastern England, spatially explicit density surface models of roe deer Capreolus capreolus and introduced muntjac Muntiacus reevesi were calibrated by thermal imaging distance sampling (recording 1590 and 400 muntjac and roe deer groups, respectively, on $567 \mathrm{~km}$ of driven transects). Models related deer density to local habitat composition, recreational intensity, and deer density (roe deer models controlled for muntjac density and vice versa) at a local grain across 1162 composite transect segments, incorporating geographical coordinates accounting for spatial autocorrelation. Abundance of both species was lower in localities with more grasslands (inter-quartile, IQ, effect size: roe $-2.9 \mathrm{deer} / \mathrm{km}^{2}$; muntjac -2.9 deer $/ \mathrm{km}^{2}$ ). Roe abundance (mean $=7 \mathrm{deer} / \mathrm{km}^{2}, \mathrm{SD}=6$ ) was greater in localities with more young stands (IQ effect size, $\left.+1.3 \mathrm{deer} / \mathrm{km}^{2}\right)$ and lower at localities with more recreationists $\left(-1.1 \mathrm{deer} / \mathrm{km}^{2}\right)$. Muntjac density $($ mean $=21$ deer $\left./ \mathrm{km}^{2}, \mathrm{SD}=10\right)$ was greater in localities with more recreationists $\left(+2.4 \mathrm{deer} / \mathrm{km}^{2}\right)$, with more mature $(\geq 46$ years $)$ stands $\left(+1.5 \mathrm{deer} / \mathrm{km}^{2}\right)$, or calcareous soil $\left(+7.1 \mathrm{deer} / \mathrm{km}^{2}\right)$. Comparison of models incorporating candidate variables and models comprising geographical coordinates only shows candidate variables to be weak predictors of deer densities. Adapting forest management to manipulate habitat and recreational access may influence local deer densities, but only subtly: effect sizes are not sufficient to mitigate deer impacts through planting vulnerable tree crops in areas avoided by deer. Effective culling remains the most viable management option.
\end{abstract}

Keywords Landscape-scale deer management $\cdot$ Forest management $\cdot$ Introduction biology $\cdot$ Species-habitat model · Sustainable hunting

Valentina Zini

v.zini@uea.ac.uk

Kristin Wäber

k.waeber@uea.ac.uk

Paul M. Dolman

p.dolman@uea.ac.uk

1 School of Environmental Sciences, University of East Anglia, Norwich NR4 7TJ, UK

2 Natural Capital Solutions, 1 Lucas Bridge Business Park, 1 Old Greens Norton Road, Towcester, Northamptonshire NN12 8AX, UK

3 National Trust, Westley Bottom, Westley, Bury Saint Edmunds IP33 3WD, UK

4 Woodland Trust, Kempton Way, Grantham, Lincolnshire NG31 6JF, UK

\section{Introduction}

Increasing deer abundance across Europe and North America has important consequences for humans and ecosystems. Deer contribute to rising incidence of tick-borne encephalitis (Jaenson et al. 2018) and Lyme borreliosis (Gilbert et al. 2012; Kilpatrick et al. 2014). Deer populations influence forest structure, composition, biodiversity, and nutrient cycling (Trdan and Vidrih 2008; Ramirez et al. 2018) and at high densities, can limit forest regeneration (Gill 1992; Côté et al. 2004), with implications for climate change mitigation strategies through land use change, woodland expansion, and increased carbon sequestration (Bastin et al. 2019; UK Climate Change Committee 2020). In the absence of top predator regulation, deer management primarily utilises shooting to control deer abundance and impacts (Department for Environment 2010); however, for ethical wildlife 
control, it is important to assess whether altering human practices could mitigate problems reducing reliance on culling (Dubois et al. 2017). Immunocontraception remains problematic, while fencing is expensive to install, costly to maintain, can cause access problems, and in some landscapes risks collision mortality of forest grouse (e.g. black grouse Tetrao tetrix, and capercaille Tetrao urugallus, Moss 2001; Baines \& Andrew 2003). The local distribution and aggregation of deer and the severity of their impacts can be influenced by habitat and landscape attributes (Hurley et al. 2012; Jarnemo et al. 2014; Royo et al. 2017; Spake et al. 2020) and forest management (Reimoser and Gossow 1996; Vospernik and Reimoser 2008; Reimoser et al. 2009; Redick and Jacobs 2020). If landscape context effects are sufficient, it may be possible to influence local deer activity-abundance away from patches where vulnerable, browsing-sensitive, tree crops are grown, thus reducing the need for lethal control (provided that any impact other than that on vegetation is absent), or conversely, it may be possible to create high deer density areas with few public recreationists, for more effective culling in terms of the effort required.

Although local habitat preferences are well understood for many deer species (Acevedo et al. 2010), landscape context effects are less well studied (though see Saïd \& Servanty 2005; Lamberti et al. 2006; Coulon et al. 2008), with the potential influence of recreational activity on deer distribution (Stankowich 2008) often overlooked. Countryside recreation is encouraged for health and human wellbeing, and levels are increasing (Johna et al. 2010); in the UK, through the Countryside and Rights of Way Act 2000 (CROW Act) large areas are now designated as open access, including much of the national forest (Edward and Kazushige 2015) where recreation is balanced with deer control to allow forest regeneration. Sustained high levels of recreational access may constrain deer management through safety concerns over shooting, but if deer are sufficiently disturbance-averse then changing the location of car-parks, access points, and pathways (Mallord et al. 2006) could potentially facilitate deer management. Building on the 'landscape of fear' hypothesis (Laundré et al. 2001), there is interest in using perceived predation risk both from stalking on foot and recreationists with dogs, to shift deer distribution away from areas requiring protection (Miller et al. 2001; Cromsigt et al. 2013). Human disturbance can affect deer habitat use and ranging behaviour (Coulon et al. 2008; Bonnot et al. 2013), and deer increase vigilance (Ciuti et al. 2012) and flush away from recreationists (Miller et al. 2001; Taylor and Knight 2003). It is unclear whether individuals in hunted populations consistently perceive recreationists as a predatory threat (Altmann 1958; Behrend and Lubeck 1968; Frid and Dill 2002), as deer may learn to avoid the characteristic behaviour of stalkers but habituate to and tolerate recreational walkers or tourists (Laundre et al. 2010).
In an extensive study across a large heterogeneous landscape, we quantified the local abundance at scales of 49.2 ha and 37.2 ha $(\mathrm{SD}=11.5, \mathrm{SD}=9.6$ for roe deer and muntjac respectively, representing aggregation or settlement, not sub-populations) of re-introduced roe deer (Capreolus capreolus, Ward 2005) and introduced invasive non-native muntjac (Muntjacus reevesi; DEFRA 2018), by extensive thermal imaging distance sampling with robust sample sizes. Local abundance was related to fine-grained habitat suitability using spatially explicit modelling that accounts for spatial intercorrelation (Miller et al. 2013). We tested habitat and landscape context features known or likely to influence local abundances of roe deer and or muntjac (Sinclair 1997; Putman and Moore 1998), and whether local deer distribution was affected by levels of recreational activity, using a spatially explicit extensively calibrated recreational pathnetwork model. Roe deer model controlled for muntjac density and vice versa muntjac models controlled for roe deer density. We a priori considered that roe would respond more strongly to recreation, as they are considered sensitive to disturbance (Hewison et al. 2001; Coulon et al. 2008; Bonnot et al. 2013), while muntjac appear tolerant of human contact at least in their introduced UK range. Last, we examined the effectiveness of landscape, habitat, and recreation as tools for vegetation impact mitigation, contrasting the spatial variation in local deer density accounting for the fine-grained variables against a null model ignoring these variables.

\section{Methods}

\section{Study area}

The study was conducted in a $187-\mathrm{km}^{2}$ conifer-dominated, lowland plantation forest landscape in eastern England, Thetford Forest, characterised by a semi-continental climate and sandy soils varying from acidic podsols to calcareous redzinas. Four deer species are resident: roe deer, muntjac, red deer (Cervus elaphus), and fallow deer (Dama dama) (Zini et al. 2019); these are managed by a professional ranger team to mitigate browsing impacts, particularly on vulnerable tree crop species. The forest landscape spans 12 'blocks' that vary in predominant soil type and configuration - from contiguous blocks in 'core' forest-dominated landscape to outlying fragments providing easier access to surrounding arable fields and grasslands (Supplementary material, Appendix A). Configuration and soil type are independent (Zini et al. 2019) providing landscape-scale replication. Planted in the 1930-1950s, plantations are managed to maturity, clearfelled, and replanted (Eycott et al. 2006). With 63\% of the forest in the second crop rotation, the felling-replanting cycle has been slowed to sustain the local forestry industry and important open-habitat species (Lin et al. 2007; 
Wright et al. 2009; Sharps et al. 2015), creating a finegrained mosaic within each block that comprises evenaged stands (mean area $=4.5 \mathrm{ha}, \mathrm{SD}=6.5$; Zini et al. 2019) permeated by an extensive trackway network. In addition to timber, carbon, and biodiversity, recreational amenity is an important social benefit of multi-criteria forestry (Oh et al. 2017) and most of the forest (75\%) is designated open access being visited by approximately 1 million people annually (1064 visitors $\mathrm{km}^{-2}$ year $^{-1}$; Armour-Chelu, Brooke \& Riley 2014).

\section{Survey method}

We used extensive nocturnal thermal imaging distance sampling conducted in late winter (January to March 2018) when low temperatures enhance thermal contrast and detection is improved by leaf-drop of deciduous under-canopy and collapse of herbaceous vegetation and bracken Pteridium aquilinum (Wäber and Dolman 2015). One-sided (from passenger-window) vehicle-based distance-transect surveys were conducted on the trackway network, using a thermal imager (Pulsar Helion XP50), while driving at $\leq 16 \mathrm{~km} / \mathrm{h}$ with headlights off, between 20.00 and $02.00 \mathrm{~h}$. Each transect was driven twice totalling $567 \mathrm{~km}$; overall sampling intensity $\left(3.02 \mathrm{~km} / \mathrm{km}^{2}\right)$ was similar in each of the 12 blocks (mean $=3.3 \mathrm{~km} / \mathrm{km}^{2}, \mathrm{SD}=0.8$; see Supplementary material, Appendix A for transect routes). Each deer detected was briefly illuminated by a roof-mounted spotlight ('lamped') allowing its distance (distance sighting $_{\text {) }}$ ) to be measured using Leica Geovid $10 \times 42$ laser rangefinder binoculars. Lamped animals remained stationary or slowly walked away; this lack of urgent escape behaviour is consistent with a lack of night hunting (professional rangers do not operate at night, and poaching gangs were not detected during extensive multiannual fieldwork). The angle of the observed animal relative

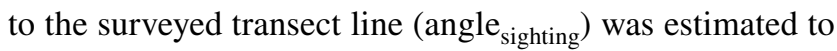
$5^{\circ}$ using an angle board and perpendicular distance (from the transect line) was calculated as.

Distance $_{\text {perpendicular }}=\cos \left(\right.$ angle $\left._{\text {sighting }}\right)$. distance $_{\text {sighting }}$

Perpendicular distance was reduced (near-truncated) by the mean verge width of the trackway class (forest roads $=8 \mathrm{~m}, \mathrm{SD}=6$; fire routes $=3.8 \mathrm{~m}, \mathrm{SD}=2.1$; forest rides $=0.60 \mathrm{~m}, \mathrm{SD}=0.2$ ) following Wäber and Dolman (2015). Stands were categorised into three visibility classes (open, dense, mature) depending on their age and whether they had been thinned (see Supplementary material, Appendix B for details), following Zini et al. (2019). Data were recorded from 2414 single-sided transect 'sections' defined by the adjacent surveyed stand (mean length $=225 \mathrm{~m}$, $\mathrm{SD}=128$ ), but these were not suitable for density surface modelling due to zero inflation and overdispersion (with potential for biased parameter estimates; Tu 2006). Consequently, sections of the same visibility class lying within $600 \mathrm{~m}$ of each other (along either side of the transect centreline) were combined for analysis as 1162 composite 'segments' (mean length $=462 \mathrm{~m}, \mathrm{SD}=297$ ), irrespective of whether they were contiguous or interrupted by sections of another visibility class (see Supplementary material, Appendix B for further details). Thus, segments may partially overlap, or be nested within, others that differed in detectability class but sampled similar neighbourhood characteristics; their lack of spatial independence was accounted for by spatially explicit analysis (see below).

\section{Candidate variables}

Local abundance of muntjac and roe deer were then related to the local intensity of recreational activity, roe deer density (only in the muntjac model), muntjac density (only in the roe deer model), and four environmental variables quantifying habitat and landscape context (Table 1), informed by the ecology of the two deer species modelled, and extracted from buffers around each transect-segment (hereafter 'localities'; for details of buffer radii, see below).

Both muntjac and roe are small- to medium-sized deer (10-18 kg and 17-23 kg respectively, Macdonald 2009) that, as concentrate selectors (Tixier et al. 1997), require more nutritious forage relative to grazers and bulk feeders. This, combined with a requirement for thermal shelter and security (Mysterud and Østbye 1995), affects the habitat selection preferences of both species (Hemami et al. 2005). In conifer-dominated plantations, density of roe deer is greater in young or mature forest stands, while density of muntjac is greatest in mature stands; both have low densities in closed-canopy (pole-stage) stands (Hemami et al. 2004) in which ground vegetation is suppressed by shade (Eycott et al. 2006). We therefore extracted the proportion of forest habitat in each locality comprising young (aged $0-5$ years since planting; Table 1$)$ and mature ( $>45$ years, following Hemami et al. 2004) stands from the Forestry England (FE) forest management database (mean polygon area $=2.9 \mathrm{ha}, \mathrm{SD}=3.0$ ) and, for surrounding areas, from the Centre for Ecology and Hydrology Land Cover Map 2015, hereafter LCM2015 (Rowland et al. 2017). Forest extracted from LCM2015 was classified as mature forest after groundtruthing. LCM2015 land cover is classified from composite summer-winter satellite images (pixel resolution 20-30 m), spatially referenced to digital cartography (Ordnance Survey MasterMap topographic layer) with a minimum polygon resolution $>0.5$ ha.

Arable fields provide high-quality food relative to the forest (Putman and Moore 1998), such that fragmented forest in arable landscapes may enhance habitat suitability for deer, and population growth (Sinclair 1997). Adult female roe deer in forest 
Table 1 Candidate variables examined in density-surface models of local roe and muntjac deer abundance, showing for each: the mean, standard deviation (SD), and coefficient of variation (CV, SD: mean) across $n=1162$ transect segments sampled for local deer abundance

\begin{tabular}{|c|c|c|c|}
\hline Candidate variable & Description & $\begin{array}{l}\text { Roe deer mean } \pm \text { SD } \\
(\mathrm{CV})\end{array}$ & $\begin{array}{l}\text { Muntjac mean } \pm \text { SD } \\
(\mathrm{CV})\end{array}$ \\
\hline Calcareous & Percentage of calcareous soil in localities & $36.7 \pm 31.3(0.8)$ & $36.7 \pm 31.3(0.8)$ \\
\hline $\begin{array}{l}\text { Recreational } \\
\text { intensity }\end{array}$ & $\begin{array}{l}\text { Interpolated modelled disturbance events of dog walkers, across } \\
\text { spring and summer in localities }\end{array}$ & $0.4 \pm 0.2(0.5)$ & $0.4 \pm 0.2(0.5)$ \\
\hline Grassland & Percentage of grassland in localities & $9.1 \pm 10.8(1.2)$ & $9.1 \pm 10.8(1.2)$ \\
\hline Arable land & $\begin{array}{l}\text { Percentage of arable (crops and freshly ploughed) land in } \\
\text { localities extracted from CROME } 2018\end{array}$ & $26.9 \pm 20.7(0.7)$ & $26.9 \pm 20.7(0.7)$ \\
\hline Young stands & Percentage of FC 1- to 5-year-old tree crop in localities & $5.7 \pm 8.5(1.5)$ & $5.7 \pm 8.5(1.5)$ \\
\hline Mature stands & Percentage of FC tree crop aged $>45$ years old in the localities & $31.8 \pm 18.2(0.6)$ & $31.8 \pm 18.2(0.6)$ \\
\hline Roe deer density & $\begin{array}{l}\text { Mean roe deer density extracted from 100-m resolution DSM } \\
\text { raster }\end{array}$ & & $68.9 \pm 4.0(0.59)$ \\
\hline Muntjac density & $\begin{array}{l}\text { Mean muntjac density extracted from 100-m resolution DSM } \\
\text { raster }\end{array}$ & $21.8 \pm 9.3(0.4)$ & \\
\hline
\end{tabular}

stands closer to arable have greater body mass (Zini et al. 2019). Cover of arable lands was extracted from the 2018 Crop Map of England (CROME2018) maps of crop types from supervised classification of Sentinel-1 Radar and Sentinel-2 Optical Satellite images. As both deer species avoided entering outdoor pig units (confirmed through extensive thermal imaging survey), these were mapped manually using satellite data derived from Sentinel-2 (Copernicus Sentinel data 2018) and excluded; remaining CROME2018 crop types were pooled as 'arable'.

Within forest habitats, calcareous soils support mineralrich and palatable forage (important during gestation and lactation, see Brown 1990) and greater plant species richness (Eycott et al. 2006; Dolman et al. 2012), while acidic soils are often dominated by less-palatable Deschampsia flexuosa (Scurfield 1954), or bracken (Marrs and Watt 2006). Highresolution mapping of forest soils (Corbett 1973) comprising 18 soil series and Cranfield NATMAP data (coarser: 9 series) for surrounding areas were reconciled to a common classification, following Zini et al. (2019). For each locality, we calculated the percentage of the combined forest and grassland area overlaying calcareous soil, excluding arable lands that provide nutrition irrespective of underlying soils that are modified by marling and fertiliser application.

We extracted the proportion of grassland from each locality, combining permanent open habitat within the forest (from the FE management database, mostly grassland but including areas of bracken and scattered scrub and, for the surrounding landscape, pooling LCM2015 classes of improved grassland, rough grassland, neutral grassland, calcareous grassland, acidic grassland, and heather (as groundtruthing showed finer-scale ecological-resolution was unreliable, Zini et al. 2019).

The local intensity of recreational activity in each locality was extracted from an empirical GIS-based Network Analysis considering path element class (forestry road, fire route, ride), path network-distance from the lowest impedance access point (considering behavioural impedance accounting for path classes, as a weighted distance, following Oh \& Jeong 2007), car parking capacity at this access point, and population density in concentric buffers around the access point, controlling for hour of day and day of week (Hornigold 2016). Calibration data comprised 1536 observations (single recreational disturbance events) collected during 1713 onehour survey visits (controlling for time of day, day of week, and season), across 180 locations (intersection nodes in the pathway network) over five years (138 points surveyed in 2007, 180 points in 2008 and 2009, and 26 in 2013-2014, for further details of methodology and recreational modelling see Supplementary material, Appendix C). The distribution of access points and housing have been stable from this earlier survey to the collection of deer data, so relative distribution of recreational intensity is expected to be unchanged. The model related the observed frequency of dog walkers for each footpath element, with mean marginal and conditional $R^{2}$ from tenfold cross validation of 0.13 and 0.41 , respectively, was interpolated across the forest-wide trackway network to predict the mean frequency of disturbance events (DE) for each footpath element.

An index of the intensity of recreational activity across the footpath elements $i$ within each segment-buffered locality $j$, was calculated as:

$\sum_{i=1}^{n} \frac{\text { pde } i * \text { length } i}{\text { areaj }}$

where $p d e_{i}$ is the predicted mean frequency of DE (per hour) on element $i$, length $h_{i}$ is the length (m) of footpath element $i$ intersected by the locality, and area $j$ is the area $\left(\mathrm{m}^{2}\right)$ of the locality.

Species-specific deer densities were resampled from 100-m resolution density surface model (DSM) rasters, 
generated from distance sampling data that incorporated geographical coordinates only (see below for more details on DSM models).

\section{Statistical analysis}

We obtained a large sample size with 1590 muntjac groups and 400 roe groups observed. We built separate DSMs for muntjac and roe deer as a two stage process, following (Miller et al. 2013). First, a detection function, accounting for the decline in detection probability with increasing perpendicular distance from the transect line, was fitted to the observations using package "Distance" (Miller 2016), accounting for segment detectability class (categorical covariate, three levels), after right-truncating data excluding the 5\% most distal observations, following Buckland et al. (2001). The best-fitting function (uniform; half-normal; or hazard-rate), adjustments (hermite; cosine; polynomial), detectability covariate, and whether group size was related to perpendicular distance (accounting for lower probability of detecting distal smaller groups) were selected by comparing model AIC (see Supplementary material, Appendix B). The selected model structure provided detection probabilities per segment, from which density per segment was calculated (accounting for effective strip width). Then, a generalised additive model (GAM) was fitted, relating density per segment to geographical coordinates of latitude and longitude using a penalised thin plate regression spline accounting for spatial autocorrelation giving a smoothed surface best-fitting the data, simultaneously considering the set of a priori candidate variables at each locality as linear predictors with Gaussian error, using package "dsm" (Marshall et al. 2017).

Variables were extracted from a buffer radius around each locality, informed both by home-range size reported in the literature and statistical analysis of our dataset. For roe deer, winter home-ranges measuring 75 ha were reported from radiotelemetry in our study area (Chapman et al. 1993), corresponding to a circular home-range of 500-m radius. A 500-m radius represented a coarser grained scale than that of individual stands (mean width $=355 \mathrm{~m}, \mathrm{SD}=60$ ); thus, we inspected a series of full DSMs (including all candidate variables, geographical coordinates as smoothing parameters, and the random effect of forest block, $n=12)$ across a range of buffer radii $(100-650 \mathrm{~m}$ at $50 \mathrm{~m}$ increment step, where $650 \mathrm{~m}$ was the maximum roe deer homerange reported see Appendix D). This showed a clear AIC minima at $300 \mathrm{~m}$ that was selected for subsequent modelling. For muntjac, the reported winter home-range from radio-telemetry of 18 ha (Chapman et al. 1993) corresponds to a circular homerange of 250-m radius. Inspecting AIC values across DSMs built with incremental buffers ranging from 100 to $700 \mathrm{~m}$ (at $50 \mathrm{~m}$ increments, maximum roe deer home range reported, see Appendix D) showed an inflexion at $250 \mathrm{~m}$ that was selected for subsequent modelling (for more detail see Supplementary material, Appendix D). Analyses were conducted in R software ( $\mathrm{R}$ core Team 2018). Variables were non-collinear across all candidate buffer widths ( $r \leq 0.7$; Freckleton 2002).

Whether candidate variables contribute to explaining local deer density, was assessed using multi-model inference in an information theoretic framework (Burnham and Anderson 2002), applied across the full set of alternative models comprising all possible combinations of candidate variables at the selected buffer radius (geographical coordinates were included in all models as smoothing parameters), using 'MuMIn' package (Bartoń 2018). A variable was considered supported if included in the $95 \%$ model confidence set (the sub-set of candidate models for which cumulative Akaike weights amount to $95 \%$ of the total) with a modelaveraged CI that did not span zero (Boughey et al. 2011). We report model-averaged coefficients and quantify effect sizes as the magnitude of change in local deer density for an increase in the candidate variable from its lower, to its upper, distribution quartile (hereafter 'inter-quartile range', IQ). As a measure of explanatory power, we report the adjusted $R^{2}$ of a model constructed comprising geographical coordinates and supported variables, as well $R^{2}$ of the model comprising geographical coordinates only — where thin plate regression splines will model spatial variation in deer density encompassing both the unmodelled effect of candidate variables as well as other variance due to unexplained effects. We expect that a model specifying the candidate variables directly would have a greater $R^{2}$ than a model using geographical coordinates only if these variables greatly affect deer density. Lastly, we predicted muntjac and roe deer densities using the supported variables and geographical coordinates in a raster of $100 \times 100 \mathrm{~m}$ and compared it to the prediction of the simpler model, comprising geographical coordinates only. To compare the change in the spatial prediction of deer numbers generated by the supported variables and the model including geographical coordinates only, we calculated the correlation coefficient between the two raster predictions.

\section{Results}

\section{Roe deer}

For roe deer, a hazard-rate detection function incorporating segment-specific detectability class best explained the decline in detectability with distance. A model that incorporated a decline in observed group size (mean $=1.7$, $\mathrm{SD}=0.8)$ at greater detection distance received similar support $(\triangle \mathrm{AIC}=0.14$, Supplementary material, Appendix $\mathrm{B})$ and was therefore excluded by parsimony, so that no group size adjustment was made in subsequent density estimation. Effective strip (half) width averaged across the three detectability classes was $90 \mathrm{~m}(\mathrm{SE}=4 \mathrm{~m})$. Of the 1162 segments, 
894 (77\%) had zero roe deer detected, while $268(23 \%)$ had one or more deer detections. Roe density across the forest (estimated for $100 \times 100 \mathrm{~m}$ raster cells) ranged from a 0.9 to $55.4 \mathrm{deer} / \mathrm{km}^{2}$ (Fig. 1). Averaging DSMs across combinations of candidate variables showed that roe deer density was lower in localities (segment-buffers of mean length $=475 \mathrm{~m}$, $\mathrm{SD}=298$, radius $=300 \mathrm{~m}$, mean area $=49.2 \mathrm{ha}, \mathrm{SD}=11.5$ ) containing a greater intensity of recreational activity (Figs. 2-3A), or a greater cover of grassland (Figs. 2-3B) and was higher in localities with a greater cover of young stands (Figs. 2-3C). Roe deer density was not affected by the extent of mature stands, arable lands, calcareous soil or muntjac density (Fig. 2). Adjusted $R^{2}$ of the DSM including supported candidate variables was 0.17 , compared to 0.13 for the model including geographical coordinates only (which nevertheless captures some effect of local variables through the geographic model). The roe deer density raster predicted by the DSM comprising geographical coordinates and supported variables was positively related to that predicted using geographical coordinates only $\left(R^{2}=0.74\right)$.

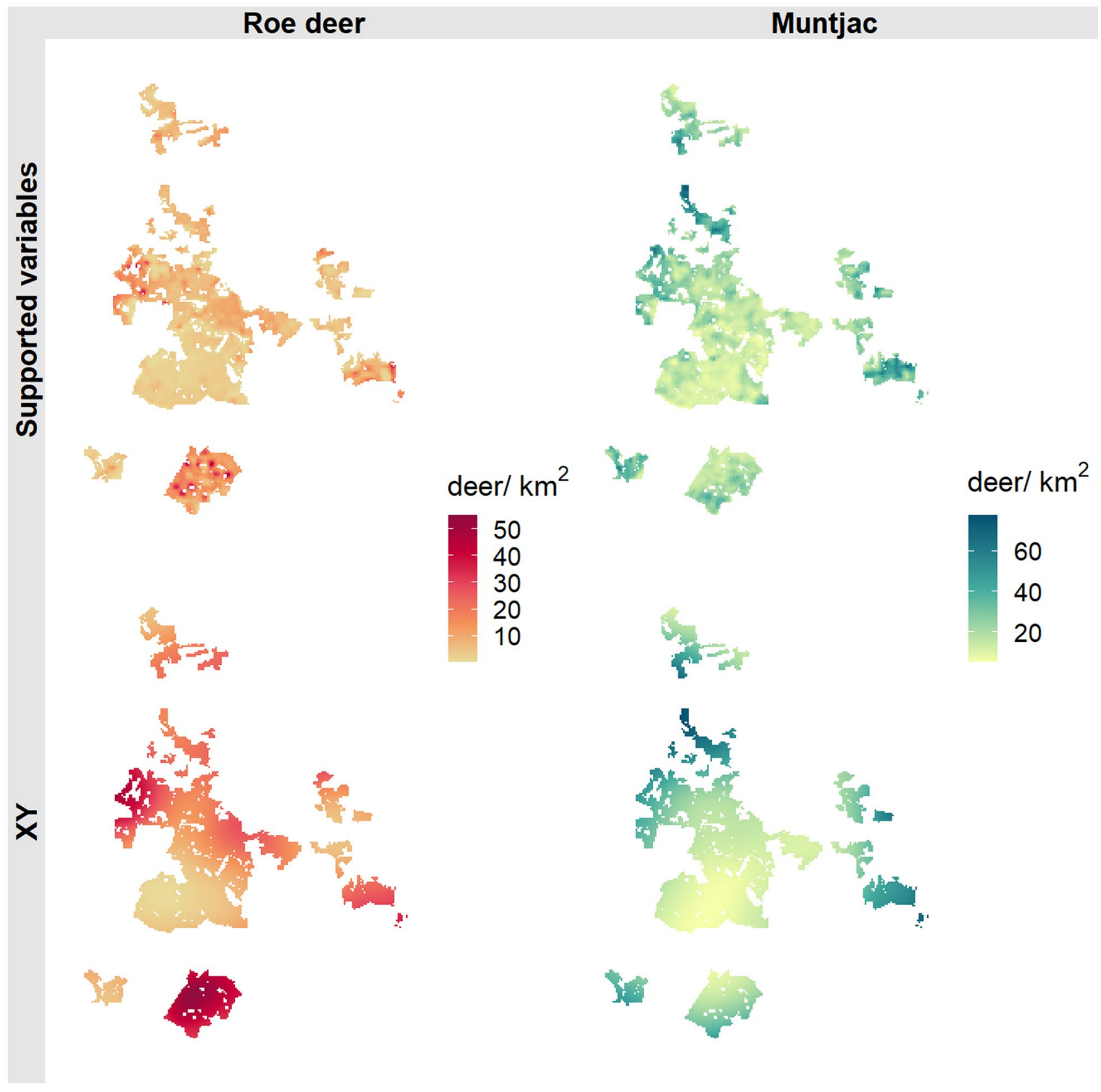

Fig. 1 Muntjac and roe deer density (individuals $/ \mathrm{km}^{2}$ ) predicted for a $100-\mathrm{m} \times 100-\mathrm{m}$ raster, by models including supported candidate variables and geographical coordinates or by models including geographical coordinates only. All models included random effects of forest block $(n=12)$ 
Fig. 2 Models of local roe deer and muntjac density showing effects of candidate habitat and landscape context variables. For each variable, modelaveraged coefficients following multi-model inference (red filled symbols non-supported variables, black filled symbols supported variables) with $95 \%$ Confidence Intervals (bars) are shown, calculated across the 95\% model confidence set. All models included the random effect of forest block $(n=12)$
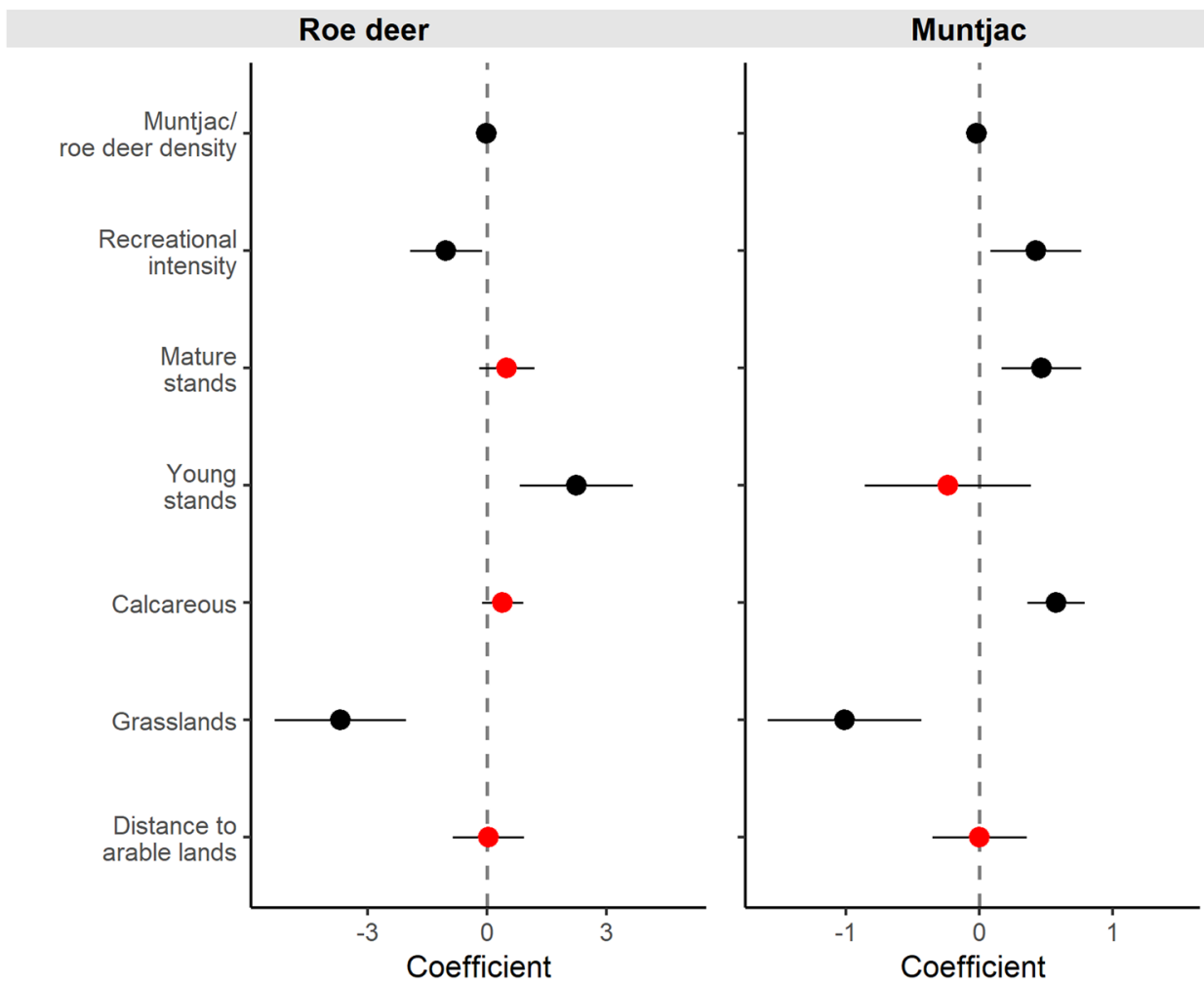

\section{Muntjac deer}

For muntjac, a hazard-rate detection function, incorporating segment-specific detectability class, best explained the decline in detectability with distance. Greater group size ( $m e a n=1.16, \mathrm{SD}=0.4)$ increased the probability of detection at greater distance $(\triangle \mathrm{AIC}=+10.75$ on removal of group-size term, Supplementary material, Appendix B); an adjustment for group size was therefore made in subsequent density estimation. Effective strip (half) width averaged across detectability classes was $75 \mathrm{~m}(\mathrm{SE}=3 \mathrm{~m})$. Of the 1162 segments, 481 (41\%) had zero deer detected, while 681 (59\%) had one or more deer detections. Muntjac density (at $100 \times 100 \mathrm{~m}$ ) ranged from 4.7 to $77.5 \mathrm{deer} / \mathrm{km}^{2}$ (Fig. 1). Averaging DSMs across combinations of candidate variables showed that muntjac density was greater in localities (segment-buffers of mean length $=475 \mathrm{~m}, \mathrm{SD}=298$, radius $=300 \mathrm{~m}$, mean area $=37.2 \mathrm{ha}, \mathrm{SD}=9.6$ ) containing greater intensity of recreational activity (Figs. 2-3D) and with greater cover of mature stands (Figs. 2-3F) or of calcareous soil (Figs. 2-3G), but was lower in localities with a greater cover of grassland (Figs. 2-3E). Muntjac density was not affected by the extent of young stands, arable lands, or muntjac density (Fig. 2). Adjusted $R^{2}$ of the DSM including supported candidate variables was 0.33 , compared to 0.30 for the model including geographical coordinates. The muntjac density raster predicted by the DSM comprising geographical coordinates and the supported variables was positively related to that predicted using the DSM comprising geographical coordinates only $\left(R^{2}=0.81\right)$.

\section{Discussion}

In this extensive landscape-scale study, with intensive replication of local habitat across multiple localities, roe deer had lower abundance in areas with highest levels of human recreational activity, while the reverse was true for muntjac. Although ecologically interesting, the effects on local deer density of recreation and other habitat variables (see below) were relatively small and thus unsuitable to be used as tools for deer impact mitigation.

\section{Local habitat and density effects}

The two species differed in their responses to forest habitat. Roe were more abundant in localities with greater percentage of young stands (inter-quartile, IQ, effect size, +1.3 deer $/ \mathrm{km}^{2}$ ), while muntjac, as previously reported (Hemami et al. 2004, 2005), were more abundant in localities with greater percentage of mature stands (IQ effect size, +2.4 deer $/ \mathrm{km}^{2}$ ). Younger stands have previously been shown to be important for roe deer populations, with increased recruitment after extensive (75\%) conifer re-planting of a woodland 

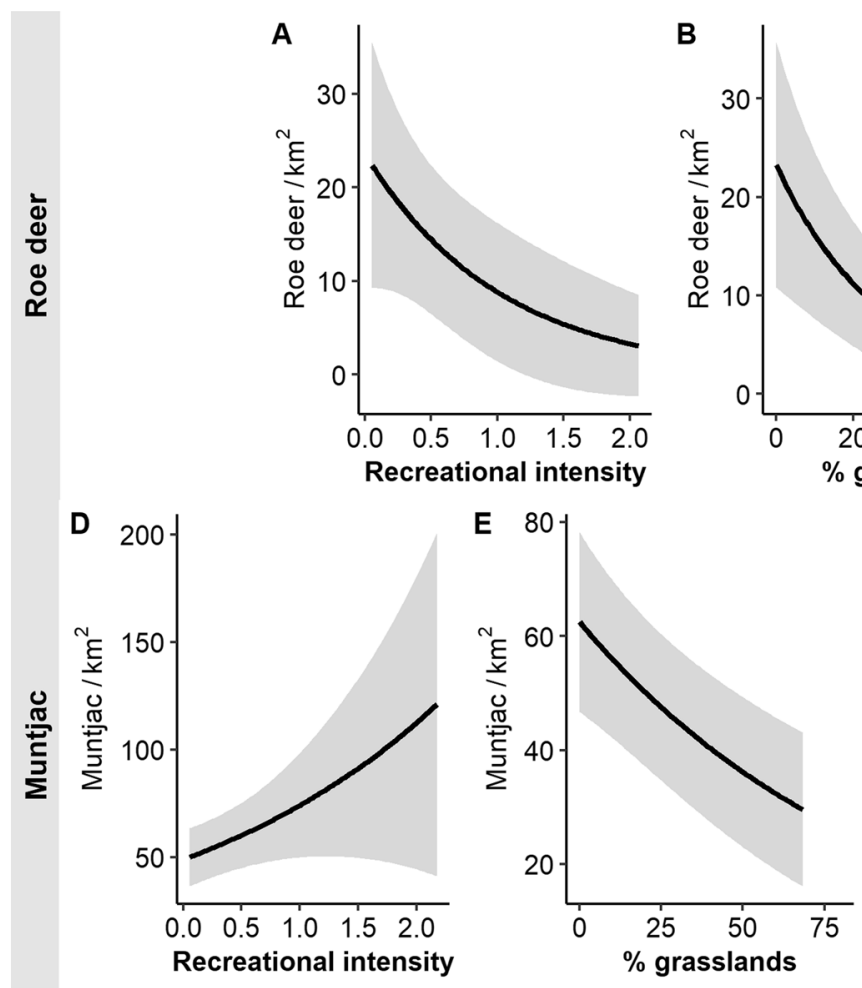

Fig. 3 Relation of local roe deer and muntjac density to supported habitat and landscape variables. Densities were predicted from density surface models including geographical coordinates and those variables supported by multi-model inference. Shown are local density of roe $(\mathbf{a}-\mathbf{c})$ and muntjac $(\mathbf{d}-\mathbf{g})$ deer in relation to: recreational inten-

in Dorset, and subsequent population declines as the forest matured (Gill et al. 1996). Earlier research in our study landscape similarly found roe deer density was higher in young stands, and muntjac density was higher in mature stands (Hemami et al. 2004). In a forest managed by clear felling and replanting, young stands offer the greatest amount of ground forage (Smolko et al. 2018), but mature stands (with open canopy) offer both ground vegetation and cover (Hemami et al. 2005). Bramble (Rubus fruticosa agg.) is widely exploited by deer (Holt et al. 2010; Wäber 2010) including roe and muntjac (Chapman et al. 1985) that both occur in higher densities where more bramble is available (Hemami et al. 2004, 2005); bramble is restricted to early and late forest growth stages by shading (Battles et al. 2001; Hemami et al. 2004). Differences in habitat use between these two species may be further explained by physiology and predator escape mode: while roe deer use open habitats to forage (Putman 1986) muntjac have shorter legs and more curved backs, adaptations that do not favour sustained running as an escape response but facilitate sheltering in dense low cover. The association of the smaller sub-tropical muntjac with dense shrub may be further explained by a greater
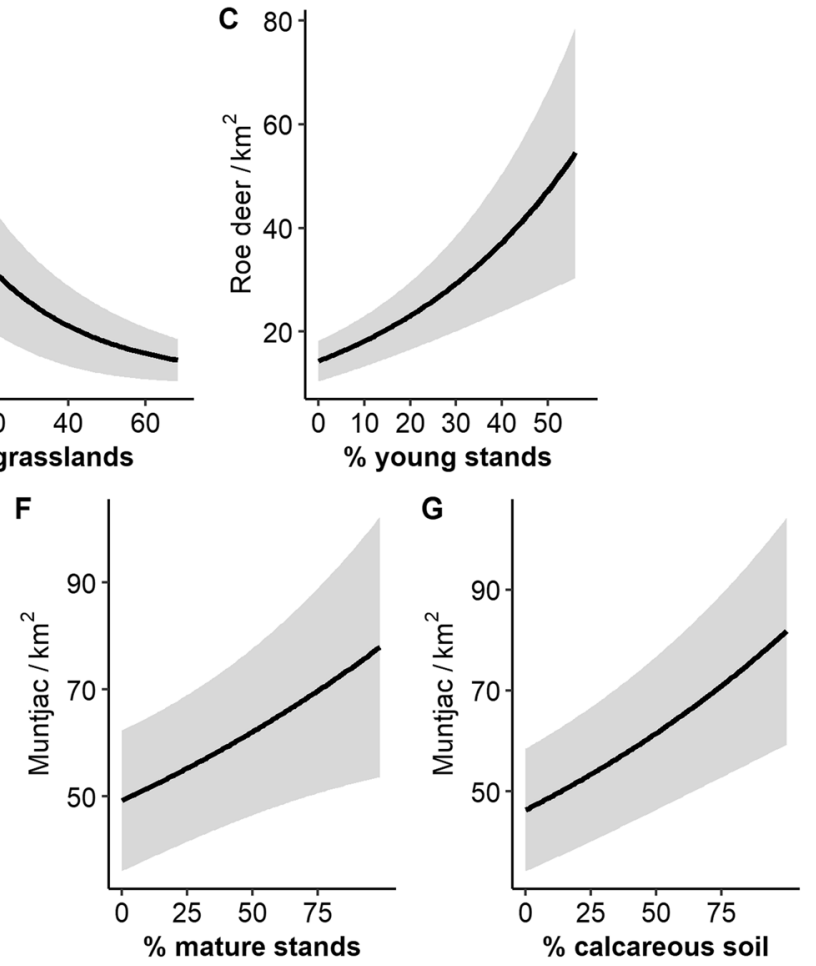

sity (number of disturbance events per hour; a, d): sum of disturbance events per hour across trackways per buffer weighted by buffer area; percentage of cover of grasslands (b, e); young stands (c); mature stands (f); and calcareous soil (g) within localities. Deer densities were predicted across the full range of each predictor variable

requirement for thermal cover, relative to the temperateboreal distribution of roe deer (Dolman and Wäber 2008).

Muntjac abundance was higher in localities with more calcareous soil (IQ effect size, $7.1 \mathrm{deer} / \mathrm{km}^{2}$ ) that have more diverse forage (Eycott et al., 2006). Muntjac are smallerbodied than roe, potentially placing them at the extreme of the browser-grazer continuum (Bodmer 1990) compared to roe, further increasing the need to select nutritious food (sensu Gordon \& Illius 1994). Roe deer and muntjac abundance were both lower in localities with a greater percentage of grassland (IQ effect size, -2.9 and $-2.6 \mathrm{deer} / \mathrm{km}^{2}$, respectively). This may be a direct consequence of habitat suitability, as both species have a concentrate-selector diet in contrast to larger grazing deer such as fallow and red deer (Gordon and Illius 1994; Obidziński et al. 2013). It is also possible that grassland extent may be a proxy for higher local abundance of these larger and potentially competitively dominant (Dolman and Wäber 2008) species that congregate around and graze within grassland areas (Thirgood 1995; Trdan and Vidrih 2008). Despite the two species using similar resources and the likelihood of these species to compete for resources (see Hemami et al. 2005), muntjac density was 
not related to roe deer density and roe deer density was not related to muntjac density.

\section{Recreational intensity}

Roe deer local abundance was negatively affected by the local frequency of dog walkers (IQ effect size, -1.1 deer/ $\mathrm{km}^{2}$ ). According to the 'human-caused predation risk' hypothesis, animals perceive disturbance from recreational activities as a predation risk (Frid and Dill 2002). This can ultimately result in avoidance of disturbed areas and increased energetic costs of antipredator behaviour reducing effective habitat quality (Gill et al. 2001). Animals may trade-off the degree of perceived risk against the resource value of a patch (Charnov 1976). For example, a study of flight responses in southwestern France showed roe deer were more vigilant when foraging in more open landscapes or when close to human settlements (Bonnot et al. 2017); in the same study area, GPS data from collared roe deer show this species uses open habitats (where forage is abundant) more during the night while using forests more during the day, likely to hide from humans; use of open habitats during the day also decreases with proximity to roads and human settlements (Bonnot et al. 2013). Similarly, avoidance of buildings and roads have been shown to be the most important factors in roe deer habitat use (Coulon et al. 2008).

Across three study sites in northern and one in southwestern France, roe deer occurred more frequently in areas with less human infrastructure (Hewison et al. 2001). Red deer and fallow deer have also been shown to be affected by recreation (Boer et al. 2004; Sibbald et al. 2011; Westekemper et al. 2018) and in Germany, red deer used zones with lower recreational activity (Coppes et al. 2017); however, differences in recreational access were applied across a bigger scale than the one examined here.

Local abundance of muntjac was positively related to the local frequency of dog walkers (IQ effect size, +1.5 deer/ $\mathrm{km}^{2}$ ); their smaller size makes it easier for them to hide in dense shrubs and avoid recreationists. Rangers in Thetford Forest avoid culling deer in areas popular with recreationists over safety concern; animals more tolerant of recreation can therefore reduce the risk of being culled by establishing their home-range in these parts of the forest. While comparison of flight distances in different environments is not an accurate method for inferring behavioural differences it is notable that in a high-throughput 'safari-park', in southern England, muntjac flight distances were only $8 \mathrm{~m}$ in non-public areas, and $11 \mathrm{~m}$ in public areas (Champion 1997), significantly less than those reported for roe deer in the Netherlands $(64 \mathrm{~m}$ when walking down wind, $41 \mathrm{~m}$ upwind, $44 \mathrm{~m}$ in calm wind (Boer et al. 2004). This short flight distance, combined with the difficulty of culling deer in areas of high recreational pressure, suggests the trade-off of occupying areas with high number of recreationists is positive for muntjac. Numerous records report muntjac in urban gardens (Harris et al. 1994), suggesting muntjac to be tolerant of proximity to humans. When comparing results of surveys of muntjac and roe deer numbers in urban environments and rural areas muntjac seems to outnumber roe deer in urban environments. Data from the BTO UK-wide Breeding Bird Survey (covering 3295 and $39411 \mathrm{~km}^{2}$ grid cells in 2006 and 2017 respectively) provide observations of some mammal species including both deer, this shows that both roe and muntjac increased in rural areas by $81 \%$ and $117 \%$ respectively between 2006 and 2017 (Harris et al. 2018).

Models incorporating geographical coordinates and the set of supported candidate variables performed better than simpler models including solely geographical coordinates; however, the increase in variance explained was small, and the majority of the variance is to be attributed to unexplained spatial variation. Densities of fallow and red deer were not accounted for in our models and are likely to account for some of the unexaplained variation in local deer density. It is possible that the influence of variables reported here, relating to local deer distribution (aggregative response, Sutherland 1983), may not affect underlying demographic processes (driven by fertility or neo-natal survival) and therefore overall numbers across the landscape. Regarding forest management, this study showed that felling and restocking tree crops may increase local roe deer abundance (as they tend to congregate more in young stands) while decreasing local muntjac abundance. As recreation appears to negatively affect roe deer local distribution, it may be possible to manage recreation (changing the spatial distribution of access points and paths accessibility) and change local density of roe deer to create 'safe refuges' favouring greater local abundance. Culling in these areas would then be simultaneously safer and more cost-effective (in terms of the effort required to achieve a given harvest, Hatter 2001). Managing recreation however would only slightly improve forest management if roe was the only deer species present, or the species having the greatest impact. This solution is not suitable for managing muntjac, for which the opposite response to recreational intensity was found. Managing recreation at a fine-scale does not appear to provide a useful tool for muntjac and roe deer management.

\section{Conclusions}

Our results show that forest management affects local deer density, but the effects found here were not strong enough to justify adapting forest management to mitigate impacts and would not allow the removal of lethal control by shooting. The variance explained by the models including the variables supported as well as the effect sizes of each variable 
were relatively low, showing little effect on local deer aggregation. Our conclusion is that culling deer continues to offer the most effective tool for local density and impact reduction. An ethical and effective culling program should start from an assessment of deer numbers to build a demographic model; culling should then be coordinated and take place at a relevant spatial scale for each culled species (Fattorini et al. 2020) and evaluation of impacts and population size will also be necessary to monitor its effectiveness (Dubois et al. 2017).

Supplementary Information The online version contains supplementary material available at https://doi.org/10.1007/s10344-021-01539-6.

Acknowledgements We are grateful to the wildlife ranger team of Thetford Forest, particularly B. Ball, D. Gunn, S. Hetherington, P. Mason, and T. Parr and Friends of Thetford Forest, for their help with thermal imaging survey. The study utilised public sector information licensed under the Open Government Licence v3.0, and Cranfield NATMAP data under FC Licence L0023/00502.

Funding This study was funded by Forestry Commission England (East England Forest District). PDM award, grant number R203625.

Availability of data and material The datasets generated and analysed in the current study are available in Mendeley data repository. http:// dx.doi.org/10.17632/8j9sndncfr.1.

\section{Declarations}

Competing interests The authors declare no competing interests.

Open Access This article is licensed under a Creative Commons Attribution 4.0 International License, which permits use, sharing, adaptation, distribution and reproduction in any medium or format, as long as you give appropriate credit to the original author(s) and the source, provide a link to the Creative Commons licence, and indicate if changes were made. The images or other third party material in this article are included in the article's Creative Commons licence, unless indicated otherwise in a credit line to the material. If material is not included in the article's Creative Commons licence and your intended use is not permitted by statutory regulation or exceeds the permitted use, you will need to obtain permission directly from the copyright holder. To view a copy of this licence, visit http://creativecommons.org/licenses/by/4.0/.

\section{References}

Acevedo P, Ward AI, Real R, Smith GC (2010) Assessing biogeographical relationships of ecologically related species using favourability functions: a case study on British deer. Divers Distrib 16:515-528. https://doi.org/10.1111/j.1472-4642.2010.00662.x

Altmann M (1958) The flight distance in free-ranging big game. J Wildl Manage 22:207. https://doi.org/10.2307/3797334

Armour-Chelu N, Brooke R, Riley R (2014) Open Habitats Implementation Plan for The Forestry Commission, Thetford Public Forest Estate, 2014 Onward. Bristol
Baines D, Andrew M (2003) Marking of deer fences to reduce frequency of collisions by woodland grouse. Biol Conserv 110:169176. https://doi.org/10.1016/S0006-3207(02)00185-4

Bartoń K (2018) MuMIn: Multi-Model Inference. R Package Version 1(42):1

Bastin J-F, Finegold Y, Garcia C, et al (2019) The global tree restoration potential. Science (80- ) 365:76-79. https://doi.org/10.1126/ science.aax 0848

Battles JJ, Shlisky AJ, Barrett RH et al (2001) The effects of forest management on plant species diversity in a Sierran conifer forest. For Ecol Manage 146:211-222. https://doi.org/10.1016/S03781127(00)00463-1

Behrend DF, Lubeck RA (1968) Summer flight behavior of white-tailed deer in two Adirondack forests. J Wildl Manage 32:615. https:// doi.org/10.2307/3798942

Bodmer RE (1990) Ungulate frugivores and the browser-grazer continuum. Oikos 57:319. https://doi.org/10.2307/3565960

de Boer HY, van Breukelen L, Hootsmans MJM, van Wieren SE (2004) Flight distance in roe deer, Capreolus capreolus and fallow deer Dama dama as related to hunting and other factors. Wildlife Biol 10:35-41. https://doi.org/10.2981/wlb.2004.007

Bonnot N, Morellet N, Verheyden H et al (2013) Habitat use under predation risk: hunting, roads and human dwellings influence the spatial behaviour of roe deer. Eur J Wildl Res 59:185-193. https://doi.org/10.1007/s10344-012-0665-8

Bonnot NC, Hewison AJM, Morellet N et al (2017) Stick or twist: roe deer adjust their flight behaviour to the perceived trade-off between risk and reward. Anim Behav 124:35-46. https://doi. org/10.1016/j.anbehav.2016.11.031

Boughey KL, Lake IR, Haysom KA, Dolman PM (2011) Effects of landscape-scale broadleaved woodland configuration and extent on roost location for six bat species across the UK. Biol Conserv 144:2300-2310. https://doi.org/10.1016/j.biocon. 2011.06.008

Brown RD (1990) Nutrition and antler development. In: Horns, proghorns and antlers. New York, pp 426-442

Buckland ST, Anderson DR, Thomas L et al (2001) Line transects. Introduction to distance sampling: estimating abundance of biological populations. Oxford University Press, Oxford, pp 104-114

Burnham KP, Anderson DR (2002) Model selection and multi-model inference. A practical information - theoretic approach, 2nd edn. New York

Champion R (1997) A behavioural and ecological study on the impact of disturbance on a free roaming population of Chinese water (Hydropotes inermis). University of London, Royal Holloway

Chapman NG, Claydon K, Claydon M et al (1993) Sympatric populations of muntjac (Muntiacus reevesi) and roe deer (Capreolus capreolus): a comparative analysis of their ranging behaviour, social organization and activity. J Zool 229:623-640. https://doi. org/10.1111/j.1469-7998.1993.tb02660.x

Chapman NG, Claydon K, Claydon M, Harris S (1985) Distribution and habitat selection by muntjac and other species of deer in a coniferous forest. Acta Theriol (warsz) 30:287-303

Charnov EL (1976) Optimal foraging theory: the marginal value theorem. Theor Popul Biol 9:129-136. https://doi.org/10.1016/00405809(76)90040-X

Ciuti S, Northrup JM, Muhly TB et al (2012) Effects of humans on behaviour of wildlife exceed those of natural predators in a landscape of fear. PLoS ONE 7:e50611. https://doi.org/10.1371/journal.pone.0050611

Coppes J, Burghardt F, Hagen R et al (2017) Human recreation affects spatio-temporal habitat use patterns in red deer (Cervus elaphus). PLoS ONE 12:e0175134. https://doi.org/10.1371/journal.pone. 0175134 
Corbett WM (1973) Breckland forest soils special survey 7. Harpenden, UK

Côté SD, Rooney TP, Tremblay J-P et al (2004) Ecological impacts of deer overabundance. Annu Rev Ecol Evol Syst 35:113-147. https://doi.org/10.1146/annurev.ecolsys.35.021103.105725

Coulon A, Morellet N, Goulard M et al (2008) Inferring the effects of landscape structure on roe deer (Capreolus capreolus) movements using a step selection function. Landsc Ecol 23:603-614. https://doi.org/10.1007/s10980-008-9220-0

CROME (2018) Crop Map of England

Cromsigt JPGM, Kuijper DPJ, Adam M et al (2013) Hunting for fear: innovating management of human-wildlife conflicts. J Appl Ecol 50:544-549. https://doi.org/10.1111/1365-2664.12076

DEFRA (2018) Tackling invasive non-native species: a new enforcement regime

Department for Environment F\& RA [DEFRA] (2010) The sustainable management of wild deer populations in England: a review of 2005-2008 and summary ofaction to March 2011. Wrexham, United Kingdom

Dolman PM, Panter CJ, Mossman HL (2012) The biodiversity audit approach challenges regional priorities and identifies a mismatch in conservation. J Appl Ecol 49:986-997. https://doi.org/10. 1111/j.1365-2664.2012.02174.x

Dolman PM, Wäber K (2008) Ecosystem and competition impacts of introduced deer. Wildl Res 35:202. https://doi.org/10.1071/ WR07114

Dubois S, Fenwick N, Ryan EA et al (2017) International consensus principles for ethical wildlife control. Conserv Biol 31:753-760. https://doi.org/10.1111/cobi.12896

Edward T, Kazushige Y (2015) Changing access and conservation mechanisms in the parks of England and Wales: a review of five policy milestones. J For Econ 61:

Eycott AE, Watkinson AR, Dolman PM (2006) Ecological patterns of plant diversity in a plantation forest managed by clearfelling. $\mathrm{J}$ Appl Ecol 43:1160-1171. https://doi.org/10.1111/j.1365-2664. 2006.01235.x

Fattorini N, Lovari S, Watson P, Putman R (2020) The scale-dependent effectiveness of wildlife management: a case study on British deer J Environ Manage 276. https://doi.org/10.1016/j.jenvman. 2020.111303

Freckleton RP (2002) On the misuse of residuals in ecology: regression of residuals vs. multiple regression. J Anim Ecol 71:542-545. https://doi.org/10.1046/j.1365-2656.2002.00618.x

Frid A, Dill LM (2002) Human-caused disturbance stimuli as a form of predation risk. Conserv Ecol 6:art11. https://doi.org/10.5751/ ES-00404-060111

Gilbert L, Maffey GL, Ramsay SL, Hester AJ (2012) The effect of deer management on the abundance of Ixodes ricinus in Scotland. Ecol Appl 22:658-667. https://doi.org/10.1890/11-0458.1

Gill JA, Norris K, Sutherland WJ (2001) Why behavioural responses may not reflect the population consequences of human disturbance. Biol Conserv 97:265-268. https://doi.org/10.1016/S00063207(00)00002-1

Gill RMA (1992) A review of damage by mammals in north temperate forests: 3. Impact on Trees and Forests Forestry 65:363-388. https://doi.org/10.1093/forestry/65.4.363-a

Gill RMA, Johnson AL, Francis A et al (1996) Changes in roe deer (Capreolus capreolus $L$.) population density in response to forest habitat succession. For Ecol Manage 88:31-41. https://doi.org/ 10.1016/S0378-1127(96)03807-8

Gordon IJ, Illius AW (1994) The functional significance of the browsergrazer dichotomy in African ruminants. Oecologia 98:167-175. https://doi.org/10.1007/BF00341469

Harris S, Chapman NG, Harris A (1994) What gardeners say about muntjac. In: Deer. pp 302-306

Harris SJ, Massimino D, Gillings S et al (2018) The 2017 BBS Report
Hatter I (2001) An assessment of catch-per-unit effort to estimate rate of change in deer and moose populations. Alces 37:71-77

Hemami MR, Watkinson AR, Dolman PM (2005) Population densities and habitat associations of introduced muntjac Muntiacus reevesi and native roe deer Capreolus capreolus in a lowland pine forest. For Ecol Manage 215:224-238. https://doi.org/10.1016/j.foreco. 2005.05.013

Hemami MR, Watkinson AR, Dolman PM (2004) Habitat selection by sympatric muntjac (Muntiacus reevesi) and roe deer (Capreolus capreolus) in a lowland commercial pine forest. For Ecol Manage 194:49-60. https://doi.org/10.1016/j.foreco.2004.01.049

Hewison AJM, Vincent JP, Joachim J et al (2001) The effects of woodland fragmentation and human activity on roe deer distribution in agricultural landscapes. Can J Zool 79:679-689. https://doi. org/10.1139/z01-032

Holt CA, Fuller RJ, Dolman PM (2010) Experimental evidence that deer browsing reduces habitat suitability for breeding common nightingales Luscinia megarhynchos. Ibis (Lond 1859) 152:335346. https://doi.org/10.1111/j.1474-919X.2010.01012.x

Hornigold K (2016) Modelling nature-based recreation to inform land management. $\mathrm{PhD}$ thesis. University of East Anglia

Hurley PM, Webster CR, Flaspohler DJ, Parker GR (2012) Untangling the landscape of deer overabundance: reserve size versus landscape context in the agricultural Midwest. Biol Conserv 146:62-71. https://doi.org/10.1016/j.biocon.2011.10.034

Jaenson TGT, Petersson EH, Jaenson DGE et al (2018) The importance of wildlife in the ecology and epidemiology of the TBE virus in Sweden: incidence of human TBE correlates with abundance of deer and hares. Parasit Vectors 11:477. https://doi.org/10.1186/ s13071-018-3057-4

Jarnemo A, Minderman J, Bunnefeld N et al (2014) Managing landscapes for multiple objectives: alternative forage can reduce the conflict between deer and forestry. Ecosphere 5:97. https://doi. org/10.1890/ES14-00106.1

Johna N, Annerstedt M, Boman M, Mattsson L (2010) Influence of outdoor recreation on self-rated human health: comparing three categories of Swedish recreationists. Scand J For Res 234-244

Kilpatrick HJ, Labonte AM, Stafford KC (2014) The relationship between deer density, tick abundance, and human cases of Lyme disease in a residential community. J Med Entomol 51:777-784. https://doi.org/10.1603/ME13232

Lamberti P, Mauri L, Merli E et al (2006) Use of space and habitat selection by roe deer Capreolus capreolus in a Mediterranean coastal area: how does woods landscape affect home range? J Ethol 24:181-188. https://doi.org/10.1007/s10164-005-0179-x

Laundré JW, Hernández L, Altendorf KB (2001) Wolves, elk, and bison: reestablishing the "landscape of fear" in Yellowstone National Park, U.S.A. Can J Zool 79:1401-1409. https://doi. org/10.1139/cjz-79-8-1401

Laundre JW, Hernandez L, Ripple WJ (2010) The landscape of fear: ecological implications of being afraid. Open Ecol J 3:1-7. https://doi.org/10.2174/1874213001003030001

Lin Y-C, James R, Dolman PM (2007) Conservation of heathland ground beetles (Coleoptera, Carabidae): the value of lowland coniferous pantations. Biodivers Conserv 16:1337-1358. https:// doi.org/10.1007/s10531-005-6231-x

Macdonald DW (2009) The Princeton encyclopedia of mammals, 1st edn. Windmill Books (Andromeda International)

Mallord JW, Dolman PM, Brown AF, Sutherland WJ (2006) Linking recreational disturbance to population size in a ground-nesting passerine. J Appl Ecol 44:185-195. https://doi.org/10.1111/j. 1365-2664.2006.01242.x

Marrs RH, Watt AS (2006) Biological flora of the British isles: Pteridium aquilinum (L.) Kuhn. J Ecol 94:1272-1321. https://doi.org/ 10.1111/j.1365-2745.2006.01177.x

Marshall L, Miller DL, Rexstad E, et al (2017) Package ‘dsm ’ 
Miller DL (2016) Package 'Distance'

Miller DL, Burt ML, Rexstad EA, Thomas L (2013) Spatial models for distance sampling data: recent developments and future directions. Methods Ecol Evol 4:1001-1010. https://doi.org/10.1111/ 2041-210X.12105

Miller SG, Knight RL, Miller CK (2001) Wildlife responses to pedestrians and dogs. Wildl Soc Bull 29:124-132

Moss R (2001) Second extinction of capercaillie (Tetrao urugallus) in Scotland? Biol Conserv 101:255-257. https://doi.org/10.1016/ S0006-3207(01)00066-0

Mysterud A, Østbye E (1995) Bed-site selection by European roe deer (Capreolus capreolus) in southern Norway during winter. Can $\mathbf{J}$ Zool 73:924-932. https://doi.org/10.1139/z95-108

Obidziński A, Kiełtyk P, Borkowski J et al (2013) Autumn-winter diet overlap of fallow, red, and roe deer in forest ecosystems, southern Poland. Open Life Sci 8:8-17. https://doi.org/10.2478/ s11535-012-0108-2

Oh B, Lee KJ, Zaslawski C et al (2017) Health and well-being benefits of spending time in forests: systematic review. Environ Health Prev Med 22:71. https://doi.org/10.1186/s12199-017-0677-9

Oh K, Jeong S (2007) Assessing the spatial distribution of urban parks using GIS. Landsc Urban Plan 82:25-32. https://doi.org/10. 1016/j.landurbplan.2007.01.014

Putman RJ (1986) Foraging by roe deer in agricultural areas and impact on arable crops. J Appl Ecol 23:91. https://doi.org/10. 2307/2403083

Putman RJ, Moore NP (1998) Impact of deer in lowland Britain on agriculture, forestry and conservation habitats. Mamm Rev 28:141-164. https://doi.org/10.1046/j.1365-2907.1998.00031.x

R core Team (2018) R: a language and environment for statistical computing

Ramirez JI, Jansen PA, Poorter L (2018) Effects of wild ungulates on the regeneration, structure and functioning of temperate forests: a semi-quantitative review. For Ecol Manage 424:406-419. https:// doi.org/10.1016/j.foreco.2018.05.016

Redick CH, Jacobs DF (2020) Mitigation of deer herbivory in temperate hardwood forest regeneration: a meta-analysis of research literature. Forests 11:1220. https://doi.org/10.3390/f11111220

Reimoser F, Gossow H (1996) Impact of ungulates on forest vegetation and its dependence on the silvicultural system. For Ecol Manage 88:107-119. https://doi.org/10.1016/S0378-1127(96)03816-9

Reimoser S, Partl E, Reimoser F, Vospernik S (2009) Roe-deer habitat suitability and predisposition of forest to browsing damage in its dependence on forest growth-Model sensitivity in an alpine forest region. Ecol Modell 220:2231-2243. https://doi.org/10.1016/j. ecolmodel.2009.05.022

Rowland CS, Morton RD, Carrasco L, et al (2017) Land cover map 2015 (vector, GB)

Royo AA, Kramer DW, Miller KV et al (2017) Spatio-temporal variation in foodscapes modifies deer browsing impact on vegetation. Landsc Ecol 32:2281-2295. https://doi.org/10.1007/ s10980-017-0568-X

Saïd S, Servanty S (2005) The influence of landscape structure on female roe deer home-range size. Landsc Ecol 20:1003-1012. https://doi.org/10.1007/s10980-005-7518-8

Scurfield G (1954) Deschampsia flexuosa (L.) Trin. J Ecol 42:225. https://doi.org/10.2307/2256995

Sharps K, Henderson IAN, Conway G, et al (2015) Home-range size and habitat use of European Nightjars. Ibis (Lond 1859) 260 272. https://doi.org/10.1111/ibi.12251

Sibbald AM, Hooper RJ, McLeod JE, Gordon IJ (2011) Responses of red deer (Cervus elaphus) to regular disturbance by hill walkers. Eur J Wildl Res 57:817-825. https://doi.org/10.1007/ s10344-011-0493-2
Sinclair ARE (1997) Carrying capacity and the overabundance of deer. The science of overabundance: deer ecology and population management. Smithsonian Institution, Washington, pp 380-394

Smolko P, Veselovská A, Kropil R (2018) Seasonal dynamics of forage for red deer in temperate forests: importance of the habitat properties, stand development stage and overstorey dynamics. Wildlife Biol 2018:wlb.00366. https://doi.org/10.2981/wlb.00366

Spake R, Bellamy C, Gill R et al (2020) Forest damage by deer depends on cross-scale interactions between climate, deer density and landscape structure. J Appl Ecol 57:1376-1390. https://doi.org/ 10.1111/1365-2664.13622

Stankowich T (2008) Ungulate flight responses to human disturbance: a review and meta-analysis. Biol Conserv 141:2159-2173. https:// doi.org/10.1016/j.biocon.2008.06.026

Sutherland WJ (1983) Aggregation and the 'Ideal Free' Distribution. J Anim Ecol 52:821. https://doi.org/10.2307/4456

Taylor AR, Knight RL (2003) Wildlife responses to recreation and associated visitor perceptions. Ecol Appl 13:951-963. https:// doi.org/10.1890/1051-0761(2003)13[951:WRTRAA]2.0.CO;2

Thirgood SJ (1995) The effects of sex, season and habitat availability on patterns of habitat use by fallow deer (Dama dama). J Zool 235:645-659. https://doi.org/10.1111/j.1469-7998.1995.tb01775.x

Tixier H, Duncan P, Scehovic J et al (1997) Food selection by European roe deer (Capreolus capreolus): effects of plant chemistry, and consequences for the nutritional value of their diets. J Zool 242:229-245. https://doi.org/10.1111/j.1469-7998.1997.tb05799.x

Trdan S, Vidrih M (2008) Quantifying the damage of red deer (Cervus elaphus) grazing on grassland production in southeastern Slovenia. Eur J Wildl Res 54:138-141. https://doi.org/10.1007/ s10344-007-0106-2

Tu W (2006) Zero-Inflated Data. In: Encyclopedia of Environmetrics. John Wiley \& Sons, Ltd, Chichester, UK

UK Climate Change Committee (2020) The Sixth Carbon Budget. The UK's Path to Net Zero

Vospernik S, Reimoser S (2008) Modelling changes in roe deer habitat in response to forest management. For Ecol Manage 255:530 545. https://doi.org/10.1016/j.foreco.2007.09.036

Wäber K (2010) Landscape scale deer management. PhD Thesis. University of East Anglia

Wäber K, Dolman PM (2015) Deer abundance estimation at landscapescales in heterogeneous forests. Basic Appl Ecol 16:610-620. https://doi.org/10.1016/j.baae.2015.06.005

Ward AI (2005) Expanding ranges of wild and feral deer in Great Britain. Mamm Rev 35:165-173. https://doi.org/10.1111/j.13652907.2005.00060.x

Westekemper K, Reinecke H, Signer J et al (2018) Stay on trails effects of human recreation on the spatiotemporal behavior of red deer Cervus elaphus in a German national park Wildlife Biol $2018 \mathrm{https}: / /$ doi.org/10.2981/wlb.00403

Wright LJ, Hoblyn RA, Green RE et al (2009) Importance of climatic and environmental change in the demography of a multi-brooded passerine, the woodlark Lullula arborea. J Anim Ecol 78:11911202. https://doi.org/10.1111/j.1365-2656.2009.01582.x

Zini V, Wäber K, Dolman PM (2019) Habitat quality, configuration and context effects on roe deer fecundity across a forested landscape mosaic. PLoS ONE 14:e0226666. https://doi.org/10.1371/journal. pone. 0226666

Publisher's Note Springer Nature remains neutral with regard to jurisdictional claims in published maps and institutional affiliations. 